\title{
A microsatellite polymorphism in the gamma interferon gene is associated with resistance to gastrointestinal nematodes in a naturally-parasitized population of Soay sheep
}

\author{
D. W. COLTMAN ${ }^{1 *}$, K. WILSON ${ }^{2}$, J. G. PILKINGTON ${ }^{1}$, M. J. STEAR ${ }^{3}$ and \\ J. M. PEMBERTON ${ }^{1}$ \\ ${ }^{1}$ Institute of Cell, Animal and Population Biology, University of Edinburgh, Edinburgh EH9 37T, UK \\ ${ }^{2}$ Institute of Biological Sciences, University of Stirling, Stirling FK9 4LA, UK \\ ${ }^{3}$ Glasgow University Veterinary School, Glasgow G61 1QH, UK
}

(Received 4 fuly 2000 ; revised 13 November 2000; accepted 15 November 2000)

\section{SUM MARY}

Free-living Soay sheep (Ovis aries) on the island of Hirta, St Kilda, Scotland, are naturally parasitized by gastrointestinal nematodes, predominantly Teladorsagia circumcincta. In this paper we show that reduced faecal egg counts (FEC) are associated with an allele at a microsatellite locus located in the first intron of the interferon gamma gene (o(IFN)- $\gamma)$ in Soay sheep lambs and yearlings, measured at approximately 4 and 16 months of age, respectively. The same allele was also associated with increased $T$. circumcincta-specific antibody (IgA) in lambs, but not associated significantly in yearlings. Flanking control markers failed to show a significant association with either FEC or IgA. These results suggest that a polymorphic gene conferring increased resistance to gastrointestinal nematode parasites is located at or near the interferon gamma gene, and support previous reports which have mapped a quantitative trait locus (QTL) for resistance to this region in domestic sheep. Our data are consistent with the idea that a functional polymorphism leading to reduced expression or efficacy of (IFN)- $\gamma$ could enhance the immune response to gastrointestinal nematodes by favouring the activity of the $\mathrm{Th}_{2}$ cell subset and antibody associated immune mechanisms.

Key words: cytokine, helminth, immunity, Ovis aries, parasite.

\section{INTRODUCTION}

The genetic basis of host variation in resistance to parasitic infection is of specific interest to animal breeders for economic reasons (Beh \& Maddox, 1996; Woolaston \& Baker, 1996) and is of fundamental importance to the study of epidemiology and infection (Read et al. 1995). Gastrointestinal nematodes are perhaps the most important parasites of domestic sheep world-wide, and Teladorsagia (formerly Ostertagia) circumcinta is the major parasite of sheep in temperate areas, causing significant morbidity and loss of production. Gastrointestinal nematode infections can be treated by anthelmintic chemotherapy; however, treatment is costly and drug resistance has evolved in all major parasite species (Prichard, 1994; Roos, 1997). For these reasons, selection for parasite resistance in domestic sheep has been undertaken in many countries (Beh \& Maddox, 1996). The next logical stage is to identify candidate genes or genetic markers for QTL for resistance to gain a more thorough understanding of

* Corresponding author: Department of Animal and Plant Sciences, Alfred Denny Building, University of Sheffield, Sheffield S10 2TN, UK.

E-mail: d.coltman@sheffield.ac.uk the genetic mechanisms underlying resistance (Schwaiger et al. 1995; Beh \& Maddox, 1996; Woolaston \& Baker, 1996; Crawford et al. 1997; Paterson, Wilson \& Pemberton, 1998).

Researchers at AgResearch, New Zealand, and CSIRO, Australia, have carried out independent full genome scans of half-sib pedigrees bred from sires derived from crosses of divergent lines selected over several generations for high and low resistance to nematode parasites (predominantly Haemonchus contortus and Trichostrongylus colubriformis). At the 26th International Conference on Animal Genetics in 1998 (Auckland, N.Z.) both groups reported finding 3-6 chromosomal regions showing evidence of segregation of QTL influencing resistance $(\mathrm{K}$. Beh and A. Crawford, personal communications). In common to both of these studies are putative QTL of large effect on the $\mathrm{q}$ arm of chromosome 3 . The most likely known candidate gene in this region is interferon gamma ((IFN)- $\gamma$ ) which has been mapped to $3 \mathrm{q} 23$ by in situ hybridization (Goldammer et al. 1996). Subsequent to finding the chromosome 3 QTL, Crawford and others performed a more detailed scan of the $\mathrm{q}$ arm of chromosome 3 using markers spaced at approximately $4 \mathrm{cM}$ intervals (Crawford \& McEwen, 1998). Four markers located 
within $2 \mathrm{cM}$ of the IFN gene, including a diallelic microsatellite located in the first intron described by Schmidt et al. (1996), showed the strongest association with resistance. Crawford \& McEwen (1998) also found a significant difference between the frequencies of the 'resistant' and 'susceptible' alleles at the (IFN)- $\gamma$ microsatellite locus between the original selection lines. In addition to the microsatellite marker, Crawford \& McEwen (1998) identified 36 single nucleotide substitutions and insertion/deletions of 1 and 8 nucleotides in their analysis of DNA sequences of the complete gene (4842 bp) from resistant and susceptible individuals. These polymorphisms, most but not all of which occur in untranslated regions, defined only 2 distinct haplotypes associated with either resistance or susceptibility in their selection lines.

While it is not yet clear if a functional polymorphism in a coding region of the (IFN)- $\gamma$ gene or in a regulatory sequence is the actual source of the QTL effect, (IFN) $\gamma$ is a cytokine that plays an important role in the regulation of the immune response to parasitic infection (Wakelin, 1996), making it a highly suggestive functional and positional candidate gene. (IFN) $-\gamma$ is secreted by $\mathrm{T}$ and NK cells, resulting in the activation of macrophages and general up-regulation of the cellmediated immune response via potentiation of $\mathrm{Th}_{1}$ cell responses, while it down-regulates the production of the $T h_{2}$ cell subset (Wakelin, 1996). $\mathrm{Th}_{2}$ cells are associated with resistance to infection from extracellular parasites such as gastrointestinal nematodes, while the $T h_{1}$ response is relatively beneficial to the survival of the nematode parasite and detrimental to host resistance (Else et al. 1994; Grencis, 1997). Any type of polymorphism leading to differential expression or receptor-binding affinity of (IFN)- $\gamma$ could thus conceivably lead to an effect on resistance to extracellular parasites.

The work of Crawford \& McEwen (1998) suggests that the (IFN)- $\gamma$ locus is associated with variation in parasite resistance in domestic sheep. The purpose of this study is to determine if microsatellite polymorphism at the o(IFN)- $\gamma$ locus (Schmidt et al. 1996) is associated with parasite resistance in a freeliving population of naturally-parasitized Soay sheep (Ovis aries) on the island of Hirta, St Kilda. Gastrointestinal nematodes, primarily Teladorsagia circumcincta, are an important selective force in this population as they are strongly implicated in overwinter mortality (Gulland, 1992; Gulland \& Fox, 1992; Gulland et al. 1993; Illius et al. 1995). Furthermore, there is clearly a genetic component to resistance in this population, as FEC is heritable (Smith et al. 1999), is affected by inbreeding (Coltman et al. 1999b) and shows associations with a protein marker (Gulland et al. 1993) and MHClinked microsatellites (Paterson, Wilson \& Pemberton, 1998).
In this study, we analyse the associations between alleles at the o(IFN)- $\gamma$ microsatellite locus and at 2 flanking microsatellite loci on FEC measured in Soay sheep at 4 and 16 months of age. In addition, we examine variation in parasite-specific IgA titre. $\operatorname{IgA}$ is an immunoglobulin which is produced in response to foreign peptides, including nematode derived molecules (Wakelin, 1996). Variation in $T$. circumcincta faecal egg output in domestic lambs is associated with variation in the $\operatorname{IgA}$ response to fourth stage larvae (Stear et al. 1995; Stear, Park \& Bishop, 1996; Stear, Strain \& Bishop, 1999b). Finally, we investigate whether polymorphism at $o(\operatorname{IFN})-\gamma$ is associated with over-winter survival. We hypothesize that if a major QTL for parasite resistance located near the (IFN)- $\gamma$ gene was segregating in Soay sheep then alleles at the o(IFN)- $\gamma$ locus which show the strongest favourable associations with FEC and IgA might also show an association with improved over-winter survival.

\section{MATERIALS AND METHODS}

\section{Study population}

The study population is located on the island of Hirta (638 hectares), in the St Kilda archipelago located approximately 50 miles west of the Outer Hebrides, Scotland $\left(57^{\circ} 49^{\prime} \mathrm{N}, 08^{\circ} 34^{\prime} \mathrm{W}\right)$. The Hirta population was founded in 1932 following the evacuation of the human population when 107 sheep (20 rams, 44 ewes, 21 ewe lambs and 22 castrated ram lambs) were introduced from the adjacent island of Soay. Since 1932 the Soay sheep have existed in an unmanaged state on Hirta.

The dynamics of the Soay sheep on Hirta are characterized by periodic over-winter crashes occurring in years of high population density coupled with harsh winter weather conditions in which up to $70 \%$ of the population may die (Clutton-Brock et al. 1991, 1992; Grenfell et al. 1992, 1998). Since 1932, the Hirta population has therefore fluctuated between 600 and 2000 individuals. Mortality during crashes is proximately caused by starvation; however, it is exacerbated by protein and nutrient deficiency caused by strongyle nematodes, primarily T. circumcincta (Gulland, 1992; Gulland \& Fox, 1992). Over-winter survival probability is negatively associated with FEC measured in the previous August (Illius et al. 1995; Coltman et al. 1999b) and animals that have been experimentally relieved of their nematode burdens show significantly improved survival during population crashes (Gulland, 1992; Gulland et al. 1993).

\section{Monitoring of survival and parasitism}

Since 1985 , over $95 \%$ of the sheep born in the Village Bay study area (comprising approximately $30 \%$ of the total island flock) have been individually 
marked, sampled for genetic analyses and monitored throughout their lives. Survival is monitored in 10 or more censuses of the study area conducted during spring, summer and autumn. In addition, systematic searches of the study area are conducted each spring. Individuals are considered to have survived the winter if they are known to be alive in May of the following year. Since 1988, approximately 50\% of the Village Bay population was caught each August and weighed and sampled for blood and faeces. Strongyle eggs in faeces are determined to the nearest 100 per gram using a modification of the McMaster technique (MAFF, 1971). Counts are predominantly made up of $T$. circumcincta; however, Teladorsagia davtiana, Ostertagia trifurcata, Trichostrongylus axei, and Trichostrongylus vitrinus are also present (Gulland \& Fox, 1992). Gulland and Fox (1992) found that $78 \%$ of all gastrointestinal worms identified in post-mortem examinations of Soay sheep were of the genus Teladorsagia, and of these $85 \%$ were $T$. circumcincta. Faecal egg count (FEC) is used in this paper as a measure of nematode parasite resistance and offers the advantages that (i) it is nondestructive, (ii) it is repeatable within individuals over short time-intervals, and (iii) it is determined by the number, size and fecundity of worms present in the gut. In this study we focus on individuals that had FEC measured as lambs (at approximately 4 months of age) or as yearlings (at approximately 16 months of age). Individuals that had previously been treated with either anthelmintics (Gulland, 1992) or hormones (Stevenson \& Bancroft, 1995) in other experimental studies were excluded from this study.

\section{$\operatorname{Ig} A$ activity}

The activity of plasma $\operatorname{IgA}$ against a somatic extract of 4th-stage larvae from $T$. circumcincta was measured by indirect ELISA. Fourth-stage larvae were harvested 4 days after infecting helminth-naïve lambs with 150000 infective larvae. The abomasum was washed with tap water and cut into strips. These strips were suspended in Baermann funnels containing PBS ( $\mathrm{pH} 7 \cdot 4$ ) at $37^{\circ} \mathrm{C}$. The larvae were then placed onto surgical swabs and the migrating larvae recovered in PBS. The recovered larvae were washed $5 \times$ in PBS, once in PBS containing $100 \mathrm{i} . \mathrm{u}$. penicillin $/ \mathrm{ml}, 0.1 \mathrm{mg}$ streptomicin $/ \mathrm{ml}, 2.5 \mu \mathrm{g}$ amphotericin $\mathrm{B} / \mathrm{ml}$, and $0.05 \mathrm{mg}$ gentamycin $/ \mathrm{ml}$ and once in Tris-inhibitor solution $(10 \mathrm{~mm}$ Tris containing $1 \mathrm{~mm}$ EDTA (disodium ethylene diamine tetraacetic acid), $1 \mathrm{~mm}$ EGTA (ethylene glycol bis (2-amino ethyl ether)- $N, N, N^{\prime} N^{\prime}$-tetraacetic acid), $1 \mathrm{~mm}$ NEM ( $N$-ethylmaleimide), $0 \cdot 1 \mu \mathrm{M}$ pepstatin, $1 \mathrm{~mm}$ PMSF (phenyl methyl sulphonyl fluoride) and $0 \cdot 1 \mathrm{~mm}$ TPCK ( $N$-tosylamide-L-phenylalanine chloromethyl ketone)). After centrifugation, the pellet was resuspended in $1 \%(\mathrm{v} / \mathrm{v})$ sodium de- oxycholate in Tris-inhibitor solution and stored at $-20{ }^{\circ} \mathrm{C}$. After thawing, the sample was homogenized on ice with a hand-held electric homogenizer (Janke \& Kunkel IKA Labortechnik). The supernatant was filtered through a $0 \cdot 2 \mu \mathrm{m}$ filter and aliquots stored at $-80{ }^{\circ} \mathrm{C}$. The protein concentration was estimated with bicinchoninic acid (Pierce) and adjusted to $5 \mu \mathrm{g} / \mathrm{ml}$ in $0.06 \mathrm{M}$ bicarbonate buffer ( $\mathrm{pH} 9.6$ ) before use.

The wells on a flat-bottomed microtitre plate (Nunc) were coated with $100 \mu$ l of parasite solution and left overnight at $4{ }^{\circ} \mathrm{C}$. The plate was washed 5 times in PBS-Tween $(0 \cdot 1 \%(\mathrm{v} / \mathrm{v})$ Tween 20 in PBS), incubated for $2 \mathrm{~h}$ with $200 \mu \mathrm{l}$ of blocking buffer ( $4 \%$ skimmed milk powder in PBS-Tween), then again washed $5 \times$ in PBS-Tween. Then $100 \mu \mathrm{l}$ of plasma sample diluted in blocking buffer were added to each of 3 wells and incubated at $37{ }^{\circ} \mathrm{C}$ for $30 \mathrm{~min}$. After another 5 washes in PBS-Tween, $100 \mu \mathrm{l}$ of a rat monoclonal anti-sheep IgA at a dilution of $1: 50$ in blocking buffer were added and incubated for $30 \mathrm{~min}$ at $37^{\circ} \mathrm{C}$. After 5 further washes in PBS-Tween, $100 \mu \mathrm{l}$ of goat anti-rat IgG conjugated to alkaline phosphatase at 1:1000 in blocking buffer were added and incubated for $30 \mathrm{~min}$ at $37^{\circ} \mathrm{C}$. After 5 final washes in PBS-Tween, $100 \mu \mathrm{l}$ of BCIP (KPL) were added and incubated for a further $30 \mathrm{~min}$ at $37^{\circ} \mathrm{C}$. The reaction was then read on a microplate reader at $635 \mathrm{~nm}$. The mean of 3 replicates from a pooled sample of helminth-naïve domestic lambs was subtracted from the sample mean and this adjusted mean was divided by the mean of 3 replicates from a pool of high-responder domestic lambs after subtracting the mean of the helminth naïve domestic lambs (Sinski et al. 1995). Three replicates from the naïve and high responder pools were included on each plate. The pool of high responder lambs was created by combining equal quantities of plasma from 6 domestic lambs that gave strong IgA responses following natural infection. The value for each sample was therefore expressed as a proportion of a positive control.

\section{Genetic analyses}

All individuals that had been sampled for FEC at age 4 and/or 16 months were typed at the o(IFN)- $\gamma$ microsatellite locus (Schmidt et al. 1996) and 2 flanking microsatellites which serve as controls, BL4 (Smith et al. 1997) and VH34 (Pierson et al. 1993) using procedures described previously (Bancroft, Pemberton \& King, 1995). o(IFN)- $\gamma$ is a tetranucleotide repeat, which is diallelic in domestic sheep, located within intron 1 of the ovine interferon gamma gene (Schmidt et al. 1996). The ovine interferon gamma gene has been cytologically mapped to 3q23-24 (Goldammer et al. 1996). Preliminary screening indicated that BL4 (chromosome 3, $208 \mathrm{cM}$ ) and VH34 (chromosome 3, $217 \mathrm{cM}$ ) 
Table 1. Summary statistics for FEC, IgA index, weight and age measured in lambs and yearlings

\begin{tabular}{|c|c|c|c|c|c|c|c|}
\hline & \multicolumn{4}{|l|}{ Lambs } & \multicolumn{3}{|l|}{ Yearlings } \\
\hline & $\begin{array}{l}\text { FEC } \\
\text { (eggs/g) }\end{array}$ & $\begin{array}{l}\operatorname{IgA} \\
\text { index }\end{array}$ & $\begin{array}{l}\text { Weight } \\
\text { (kg) }\end{array}$ & $\begin{array}{l}\text { Age } \\
\text { (days) }\end{array}$ & $\begin{array}{l}\text { FEC } \\
\text { (eggs/g) }\end{array}$ & $\operatorname{IgA}$ & $\begin{array}{l}\text { Weight } \\
\text { (kg) }\end{array}$ \\
\hline$N$ & 904 & 364 & 945 & 904 & 325 & 107 & 394 \\
\hline $\begin{array}{l}\text { Arithmetic } \\
\text { mean }\end{array}$ & 611 & $0 \cdot 83$ & $13 \cdot 6$ & $116 \cdot 4$ & 342 & $1 \cdot 91$ & $19 \cdot 5$ \\
\hline S.D. & 671 & $0 \cdot 83$ & $2 \cdot 7$ & $8 \cdot 4$ & 361 & $0 \cdot 87$ & $3 \cdot 9$ \\
\hline Range & $0-6000$ & $0 \cdot 04-4 \cdot 66$ & $5 \cdot 4-22 \cdot 2$ & $41-152$ & $0-2100$ & $0 \cdot 04-3 \cdot 82$ & $11 \cdot 4-31 \cdot 8$ \\
\hline
\end{tabular}

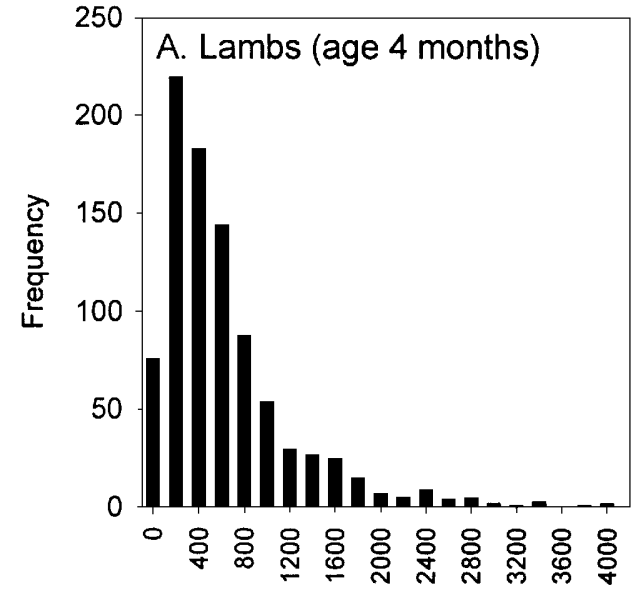

FEC

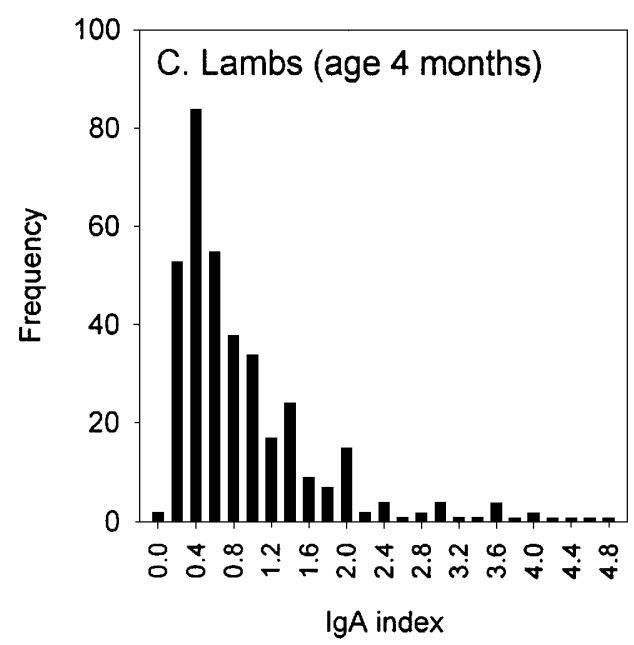

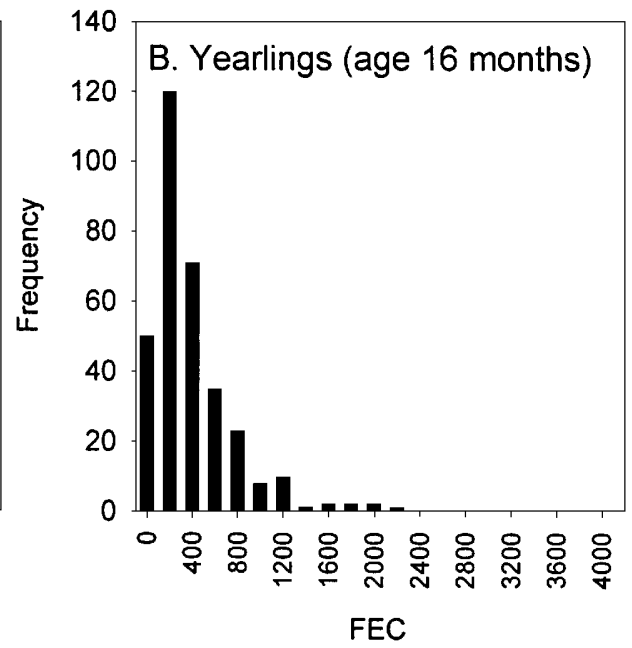

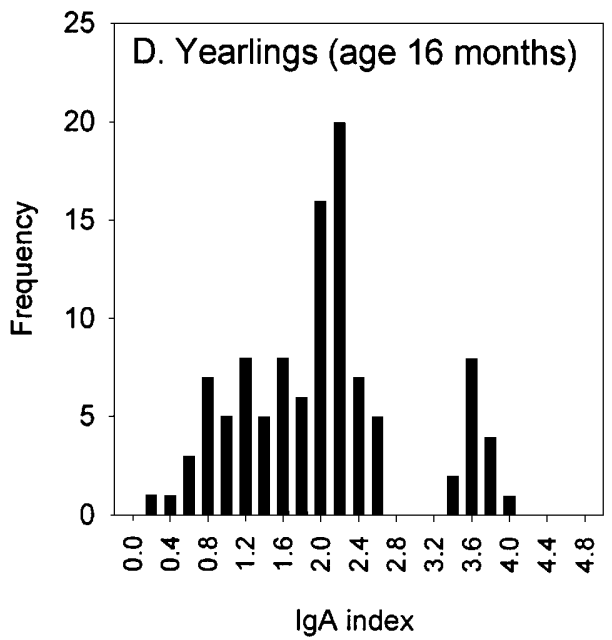

Fig. 1. Frequency distributions of FEC and IgA assay data collected in lambs and yearlings.

are the most polymorphic microsatellite markers in Soay sheep that are located on the $\mathrm{q}$ arm of chromosome 3 in close proximity to o(IFN)- $\gamma$. VH34 is used routinely in our laboratory for paternity analysis (Coltman et al. $1999 a$; Pemberton et al. 1999). Deviations from Hardy-Weinberg equilibrium were tested using exact tests implemented in the GENEPOP 3.1 program (Raymond \& Rousset, 1995). Rare alleles with frequency of less than 0.01 were pooled with the closest size class for linkage analyses. Linkage disequilibrium was analysed using GENETIX (Laboratoire Génome et Populations, Montpellier, France) which estimates the unbiased linkage disequilibrium coefficient between 2 alleles as

$D_{i j}=(N / N-1)\left(\left(T_{i j} / N\right)-2 p_{i} p_{j}\right)$,

where $T_{i j}$ is the number of times the allele $i$ and $j$ appear together in the same individual, $N$ is the total number of genotypes, $p_{i}$ indicates the frequency of the $i$ th allele at one locus and $p_{j}$ indicates the frequency of the $j$ th allele at another locus. The 
Table 2. Correlations between FEC, IgA and weight measured in 4 months and 16 months of age

(Values in the table are Spearman's rank correlation coefficient, sample size and $P$ values, respectively. In cases where both variables were normally distributed, the Pearson correlation coefficient is shown denoted by the superscript ' $p$ '. Tablewide statistically significant correlations following sequential Bonferroni correction (Rice, 1989) for multiple comparisons are indicated in italic type.)

\begin{tabular}{|c|c|c|c|c|c|c|}
\hline & $\begin{array}{l}\text { FEC } \\
\text { (4 months) }\end{array}$ & $\begin{array}{l}\text { IgA } \\
\text { (4 months) }\end{array}$ & $\begin{array}{l}\text { Weight } \\
\text { (4 months) }\end{array}$ & $\begin{array}{l}\text { FEC } \\
\text { (16 months) }\end{array}$ & $\begin{array}{l}\text { IgA } \\
\text { (16 months) }\end{array}$ & $\begin{array}{l}\text { Weight } \\
\text { (16 months) }\end{array}$ \\
\hline $\begin{array}{l}\text { Age in } \\
\text { days } \\
\text { (4 months) }\end{array}$ & $\begin{array}{l}-0 \cdot 030 \\
902 \\
0 \cdot 368\end{array}$ & $\begin{array}{l}+0 \cdot 253 \\
358 \\
<0 \cdot 001\end{array}$ & $\begin{array}{l}+0 \cdot 201^{\mathrm{p}} \\
902 \\
<0 \cdot 001\end{array}$ & & & \\
\hline $\begin{array}{l}\text { FEC } \\
\text { (4 months) }\end{array}$ & & $\begin{array}{l}-0 \cdot 177 \\
358 \\
<0 \cdot 001\end{array}$ & $\begin{array}{l}-0 \cdot 240 \\
90 \\
<0 \cdot 001\end{array}$ & $\begin{array}{l}+0 \cdot 254 \\
151 \\
\quad 0 \cdot 0017\end{array}$ & $\begin{array}{l}+0.066 \\
67 \\
0.62\end{array}$ & $\begin{array}{l}-0 \cdot 143 \\
220 \\
0 \cdot 033\end{array}$ \\
\hline $\begin{array}{l}\text { IgA } \\
\text { (4 months) }\end{array}$ & & & $\begin{array}{c}-0 \cdot 057 \\
362 \\
0 \cdot 27\end{array}$ & $\begin{array}{l}-0 \cdot 256 \\
56 \\
0 \cdot 053\end{array}$ & $\begin{array}{l}+0.448 \\
33 \\
0.009\end{array}$ & $\begin{array}{l}+0 \cdot 116 \\
85 \\
0 \cdot 28\end{array}$ \\
\hline $\begin{array}{l}\text { Weight } \\
\text { (4 months) }\end{array}$ & & & & $\begin{array}{c}+0 \cdot 057 \\
192 \\
0 \cdot 43\end{array}$ & $\begin{array}{l}+0 \cdot 197 \\
71 \\
0 \cdot 094\end{array}$ & $\begin{array}{l}+0 \cdot 619^{p} \\
261 \\
<0 \cdot 001\end{array}$ \\
\hline $\begin{array}{l}\text { FEC } \\
\text { (16 months) }\end{array}$ & & & & & $\begin{array}{c}+0 \cdot 024 \\
94 \\
0 \cdot 81\end{array}$ & $\begin{array}{c}+0 \cdot 012 \\
323 \\
0 \cdot 823\end{array}$ \\
\hline $\begin{array}{l}\text { IgA } \\
\text { (16 months) }\end{array}$ & & & & & & $\begin{array}{l}+0 \cdot 100 \\
101 \\
0 \cdot 30\end{array}$ \\
\hline
\end{tabular}

correlation coefficient provides a measure which is normalized by allele frequencies and is calculated as

$R_{i j}=\frac{D_{i j}}{\Sigma_{i}^{j}\left(\left(p_{i}\left(1-p_{i}\right)+C_{i}\right)\left(p_{j}\left(1-p_{j}\right)+C_{j}\right)\right.}$,

where $C_{i}$ is a correction term equal to the observed minus expected frequencies of homozygotes for the $i$ th allele in the population. The significance of $R$ for each pair of alleles is tested as

$\chi^{2}=N R_{i j}^{2}$

and over all alleles for each pair of loci as

$\chi^{2}=N S_{i} S_{j}\left(D_{i j}^{2} / p_{i} p_{j}\right)$

where $S_{i}$ gives the variance in the frequency of allele $i$ (Weir, 1979).

\section{Statistical analyses}

Associations between microsatellite genotypes and FEC, IgA and over-winter survival were analysed using generalized linear models (GLMs). This approach enabled us to take into account the specific error structure of each response variable, and to incorporate other known sources of variation simultaneously. Models were constructed separately for lambs and yearlings for 4 reasons. First, sources of variation in survival and FEC of Soay sheep are known to differ between age classes (Coltman et al. 1999 b; Paterson et al. 1998). Second, the degree of aggregation in FEC differs between lambs and yearlings (see Table 1 and Fig. 1). Third, 10-15\% of the individuals considered in this study were measured for FEC and $\operatorname{IgA}$ both as lambs and yearlings, therefore models including both age classes would suffer from pseudoreplication. Finally, genetic effects on parasite resistance might be expected to change with age. For example, Bishop et al. (1996) reported that genetic variation for acquired resistance to strongyles increases with age from birth to 6 months in Scottish Blackface sheep within an anthelmintic regime.

For each trait and age-class, a single model was constructed in the following manner. First, nongenetic sources of variation were fitted as main effects. In all models, sex (factor: male versus female), year (factor) and weight (continuous) were entered. Age (continuous: days since birth) and twin status (factor: twin versus singleton) were also fitted to models for lambs. The significance of each predictor variable was then tested by comparing the deviance explained by the full model to a model not containing the term in question (Crawley, 1993). The non-genetic full model was reduced by removing each non-significant term, starting with the term having the highest $P$ value. Following reduction, the resultant model consists of only significant terms (the non-genetic minimal model). In order to determine which locus showed the strongest statistical association with resistance, genetic terms for all 3 loci were then fitted to the minimal non-genetic model simultaneously, and the 
Table 3. Allele frequencies, observed $\left(\mathrm{H}_{\mathrm{obs}}\right)$ and expected heterozygosities $\left(\mathrm{H}_{\text {exp }}\right)$ of microsatellite loci associated with the interferon gamma gene in Soay sheep

$\left(\mathrm{P}_{\mathrm{HWE}}\right.$ indicates probability of deviation of observed genotype frequencies from Hardy-Weinberg expectations.)

\begin{tabular}{|c|c|c|c|c|c|}
\hline \multicolumn{2}{|c|}{ BL4 $(N=894)$} & \multicolumn{2}{|c|}{$\mathrm{o}(\mathrm{IFN})-\gamma(N=882)$} & \multicolumn{2}{|c|}{ VH34 $(N=1059)$} \\
\hline $\begin{array}{l}\text { Allele size } \\
\text { (bp)* }\end{array}$ & Frequency & $\begin{array}{l}\text { Allele size } \\
\text { (bp) }\end{array}$ & Frequency & $\begin{array}{l}\text { Allele size } \\
\text { (bp) }\end{array}$ & Frequency \\
\hline 153 & $0 \cdot 101$ & 126 & $0 \cdot 625$ & 77 & $0 \cdot 113$ \\
\hline 155 & $0 \cdot 481$ & 130 & $0 \cdot 375$ & 85 & $0 \cdot 007$ \\
\hline 157 & $0 \cdot 394$ & & & 95 & $0 \cdot 639$ \\
\hline 161 & $0 \cdot 001$ & & & 99 & $0 \cdot 070$ \\
\hline 167 & $0 \cdot 022$ & & & 103 & $0 \cdot 171$ \\
\hline $\mathrm{H}_{\mathrm{obs}}$ & $0 \cdot 603$ & & $0 \cdot 489$ & & $0 \cdot 551$ \\
\hline $\mathrm{H}_{\mathrm{exp}}$ & $0 \cdot 602$ & & $0 \cdot 469$ & & $0 \cdot 545$ \\
\hline $\mathrm{P}_{\mathrm{HWE}}^{\exp }$ & $0 \cdot 782$ & & $0 \cdot 124$ & & $0 \cdot 108$ \\
\hline
\end{tabular}

* bp, base pairs.

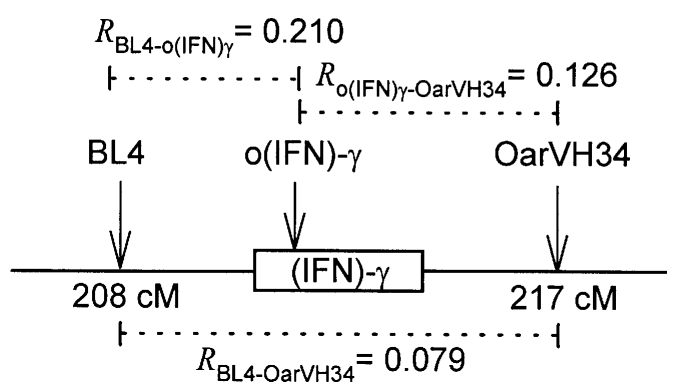

Fig. 2. Location of microsatellite markers in relation to the (IFN)- $\gamma$ gene. Map positions are from de Gortari et al. (1998). $\mathrm{R}$ indicates the correlation coefficient of linkage disequilibrium based on the observed genotype frequencies in the total sample.

full genetic model reduced in an identical manner to the non-genetic model, starting with the locus having the highest $P$ value. Locus terms were fitted under an allelic substitution model in which the count of each allele present at each locus is fitted as a continuous variable (e.g. Paterson et al. 1998). Alleles with frequency less than 0.05 were pooled with their nearest neighbouring size class to ensure adequate sample sizes. Due to linkage disequilibrium, the effects of any 1 locus are expected to be aliased with another locus to a certain extent; therefore each locus was also tested alone in the minimal non-genetic model to determine if each locus would have explained significant variation in the absence of other genetic information.

\section{Effects of maternal genotype}

Confounding maternal genetic effects on $\operatorname{IgA}$ and FEC could arise if there was significant maternally derived antibody circulating in lambs at the time of sampling, and there was a relationship between the maternal genotype and maternal IgA production. In order to assess whether the genetic effects observed in the analyses of IgA and FEC were confounded by the effects of the maternal genotype, we also fitted the maternal o(IFN)- $\gamma$ genotype to models where significant genetic effects were found.

\section{RESULTS}

A total of 1076 individuals had FEC measured as lambs $(N=904)$ and/or yearlings $(N=325$, Table 1). A total of 153 individuals was sampled at both ages. Arithmetic mean FEC was approximately 2 -fold higher in lambs than in yearlings (Table 1), whereas the mean $\operatorname{IgA}$ index was more than twice as high in yearlings than in lambs (Table 1). Frequency distributions of both variables in each age class are shown in Fig. 1. Distributions of both FEC and IgA tended to exhibit greater skew in lambs than in yearlings (skewness $=2 \cdot 1$ versus $0 \cdot 4$ for $\operatorname{IgA}$, and $3 \cdot 0$ versus $2 \cdot 0$ for $\mathrm{FEC}$ for lambs and yearlings, respectively). In lambs, FEC was negatively associated with IgA and body weight, but not significantly associated with age in days since birth (Table 2). However, both IgA and weight increased significantly with age in days since birth. The correlation between IgA and FEC in lambs aged 4 months remained negative after correcting IgA for age in days since birth (partial correlation $=-0 \cdot 125, P=$ $0.018)$. FEC, IgA and weight were not correlated in sheep measured at 16 months of age. FEC, IgA and weight were positively correlated within individuals that were measured at both 4 and 16 months of age; however, only the correlation between weight measurements was statistically significant after sequential Bonferroni correction (Rice, 1989) for multiple comparisons (Table 2). 
Table 4. Correlation between alleles at interferon gamma-linked microsatellite loci in Soay sheep

(Table-wide statistically significant correlations are indicated following sequential Bonferroni correction (Rice, 1989) for multiple comparisons $\left({ }^{*} P<0.005\right.$, ** $P<0 \cdot 001)$.)

\begin{tabular}{llllll}
\hline \hline & o(IFN)- $\gamma-126$ & BL4-153 & BL4-155 & BL4-157 & BL4-167 \\
\hline o(IFN)- $\gamma-126$ & & $-0 \cdot 234 * *$ & $-0 \cdot 278^{* *}$ & $+0 \cdot 392 * *$ & $+0 \cdot 116^{* *}$ \\
VH34-77 & $-0 \cdot 281 * *$ & $-0 \cdot 075$ & $+0 \cdot 100^{*}$ & $-0 \cdot 048$ & $-0 \cdot 047$ \\
VH34-95 & $+0 \cdot 037$ & $+0 \cdot 134 * *$ & $+0 \cdot 077$ & $-0 \cdot 122 * *$ & $-0 \cdot 117 * *$ \\
VH34-99 & $+0 \cdot 179 * *$ & $-0 \cdot 103 *$ & $-0 \cdot 072$ & $+0 \cdot 031$ & $+0 \cdot 356 * *$ \\
VH34-103 & $+0 \cdot 050$ & $-0 \cdot 029$ & $-0 \cdot 136^{* *}$ & $+0 \cdot 167 * *$ & $-0 \cdot 050$ \\
\hline \hline
\end{tabular}

Table 5. Generalized linear models of FEC in Soay sheep lambs (A) and yearlings (B)

(Models were fitted assuming a negative binomial error structure. The change in total deviance explained is equal to the amount of deviance explained by that term when fitted last, divided by the sum of the explained deviances of all terms when fitted last, expressed as a percentage of the total deviance explained by the full model. Coefficients for significant terms and their standard errors were estimated from 2500 bootstrap replications of the reduced genetic model, and for specific allele effects were estimated similarly from a restricted model including only that allele term. $P$ values indicate the significance estimated asymptotically by deletion testing.)

\begin{tabular}{|c|c|c|c|c|}
\hline Term & D.F. & $\begin{array}{l}\text { Change in total } \\
\text { deviance } \\
\text { explained }(\%)\end{array}$ & Coefficient (s.E.) & $P$ \\
\hline \multicolumn{5}{|c|}{ A Lambs (age 4 months): $N=684$, total deviance $=1109 \cdot 0$, residual deviance $=754 \cdot 2$} \\
\hline Year & 10 & $20 \cdot 9$ & & $<0 \cdot 0001$ \\
\hline Weight & 1 & $5 \cdot 3$ & $-0 \cdot 101(0 \cdot 013)$ & $<0 \cdot 0001$ \\
\hline Sex & 1 & $4 \cdot 3$ & Male: $0 \cdot 218(0 \cdot 034)$ & $<0 \cdot 0001$ \\
\hline Twin & 2 & $1 \cdot 0$ & $\begin{array}{r}\text { Twin: } 0.084(0.043) \\
\text { Single: }-0.096(0.043)\end{array}$ & $0 \cdot 015$ \\
\hline$o(\operatorname{IFN})-\gamma$ & 1 & $0 \cdot 5$ & $\begin{array}{r}126 \text { ': }-0 \cdot 101(0 \cdot 048) \\
\text { '130': } 0 \cdot 101(0 \cdot 048)\end{array}$ & $0 \cdot 047$ \\
\hline \multicolumn{5}{|c|}{ Rejected terms } \\
\hline Age & 1 & & & $0 \cdot 82$ \\
\hline BL4 & 2 & & & 0.53 \\
\hline VH34 & 3 & & & $0 \cdot 91$ \\
\hline \multicolumn{5}{|c|}{ B Yearlings (age 16 months) $: N=270$, total deviance $=394 \cdot 8$, residual deviance $=296 \cdot 3$} \\
\hline Year & 10 & $8 \cdot 2$ & & $<0 \cdot 0001$ \\
\hline Weight & 1 & $3 \cdot 4$ & $-0.063(0.017)$ & $<0 \cdot 0001$ \\
\hline Sex & 1 & $4 \cdot 4$ & Male: $0.423(0.062)$ & $0 \cdot 00015$ \\
\hline$o(\operatorname{IFN})-\gamma$ & 1 & $1 \cdot 9$ & $\begin{array}{l}\text { '126’: }-0 \cdot 227(0 \cdot 081) \\
' 130 \text { ': } 0.227(0 \cdot 080)\end{array}$ & $0 \cdot 0042$ \\
\hline \multicolumn{5}{|c|}{ Rejected terms } \\
\hline BL4 & 2 & & & $0 \cdot 82$ \\
\hline VH34 & 3 & & & 0.95 \\
\hline
\end{tabular}

In the total sample, 894,882 and 1059 individuals were typed at the BL4, o(IFN)- $\gamma$ and VH34 microsatellite loci, respectively, with 817 individuals typed at all 3 loci. Missing genotypes can probably be attributed to failures to amplify by PCR due to degraded template DNA rather than non-amplifying or null alleles because there was no evidence for departure from Hardy-Weinberg equilibrium at any locus (Table 3).

The o(IFN)- $\gamma$ locus appeared diallelic in Soay sheep (Table 3), with 2 alleles separated by 4 base pairs (bp), the equivalent of 1 repeat unit (Schmidt et al. 1996). The $126 \mathrm{bp}$ allele in the Soay sheep is the same length as the ' $\mathrm{B}$ ' allele associated with resistance reported by Crawford \& McEwen (1998). BL4 was moderately polymorphic with 3 alleles having frequency greater than 0.05 (Table 3). The very rare $161 \mathrm{bp}$ allele (frequency $=0.001$ ) was pooled with the $157 \mathrm{bp}$ allele for linkage analyses, and both the 161 and $167 \mathrm{bp}$ alleles with frequency less than 0.05 were pooled with the $157 \mathrm{bp}$ allele for GLM analyses. OarVH34 also had 4 alleles at frequency greater than 0.05 and the rare $85 \mathrm{bp}$ allele was pooled with the $77 \mathrm{bp}$ allele for all analyses 
Table 6. Generalized linear models of IgA titre in Soay sheep lambs (A) and yearlings (B)

(Models were fitted to log transformed data assuming a normal error structure. The change in total deviance explained is equal to the amount of deviance explained by that term when fitted last, divided by the sum of the explained deviances of all terms when fitted last, expressed as a percentage of the total deviance explained by the full model. Coefficients for significant terms and their standard errors were estimated from 2500 bootstrap replications of the reduced genetic model, and for specific allele effects were estimated similarly from a restricted model including only that allele term. $P$ values indicate the level of statistical significance estimated asymptotically by deletion testing.)

\begin{tabular}{|c|c|c|c|c|}
\hline Term & D.F. & $\begin{array}{l}\text { Deviance } \\
\text { explained }(\%)\end{array}$ & Coefficient (s.E.) & $P$ \\
\hline \multicolumn{5}{|c|}{ A Lambs (age 4 months) $: N=329$, total deviance $=45 \cdot 8$, residual deviance $=32 \cdot 4$} \\
\hline Year & 4 & $17 \cdot 4$ & & $<0 \cdot 0001$ \\
\hline Age & 1 & $3 \cdot 4$ & $+0.0095(0.0030)$ & $0 \cdot 0028$ \\
\hline Twin & 2 & $4 \cdot 2$ & $\begin{array}{r}\text { Twin: } 0.052(0.023) \\
\text { Single: }-0.073(0.025)\end{array}$ & $0 \cdot 0039$ \\
\hline $\mathrm{o}(\mathrm{IFN})-\gamma$ & 1 & $2 \cdot 2$ & $\begin{array}{l}' 126 \text { ': +0.062 (0.026) } \\
\text { '130': -0.062 (0.026) }\end{array}$ & $0 \cdot 011$ \\
\hline \multicolumn{5}{|c|}{ Rejected terms } \\
\hline Sex & 1 & & & $0 \cdot 95$ \\
\hline Weight & 1 & & & $0 \cdot 10$ \\
\hline BL4 & 2 & & & $0 \cdot 07$ \\
\hline VH34 & 3 & & & $0 \cdot 31$ \\
\hline \multicolumn{5}{|c|}{ B Yearlings (age 16 months) $: N=101$, total deviance $=10 \cdot 4$, residual deviance $=8 \cdot 3$} \\
\hline Year & 3 & $19 \cdot 92$ & & $<0 \cdot 0001$ \\
\hline \multicolumn{5}{|c|}{ Rejected terms } \\
\hline Sex & 1 & & & $0 \cdot 17$ \\
\hline Weight & 1 & & & $0 \cdot 34$ \\
\hline BL4 & 2 & & & 0.63 \\
\hline VH34 & 3 & & & $0 \cdot 67$ \\
\hline$o(\operatorname{IFN})-\gamma$ & 1 & & & $0 \cdot 19$ \\
\hline
\end{tabular}

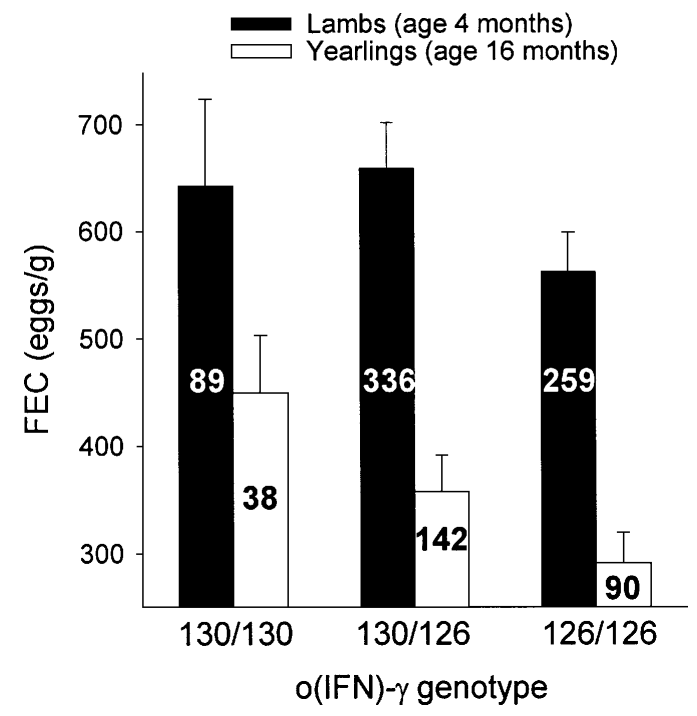

Fig. 3. Arithmetic mean FEC observed in lambs and yearlings (age 4 and 16 months) plotted by o(IFN)- $\gamma$ microsatellite genotype. Numbers within the columns give sample size and bars indicate standard error.

(Table 3). All 3 loci were found to be in significant linkage disequilibrium (Fig. 2, $P<0.001$ for all 3 pairwise tests). Analysis of pairwise allele associations indicated (Table 4) that there was 1 major haplotype segregating with each o(IFN)- $\gamma$ allele: $\quad[\mathrm{BL} 4(157) / \mathrm{BL} 4(167)+\mathrm{o}(\mathrm{IFN})-\gamma(126)+$ VH34(99)] and [BL4(155) $+\mathrm{o}(\mathrm{IFN})-\gamma(130)+$

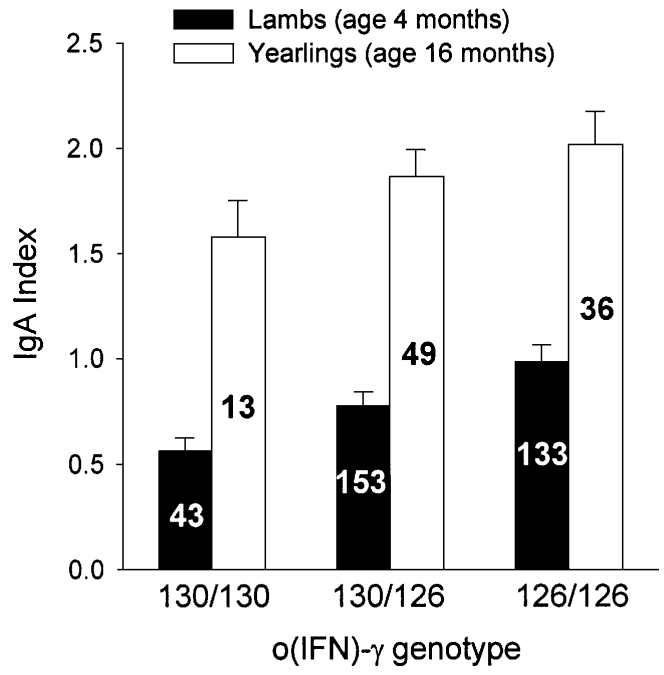

Fig. 4. Arithmetic mean IgA index observed in lambs and yearlings (age 4 and 16 months) plotted by $o($ IFN) $-\gamma$ microsatellite genotype (right). Numbers within the columns give sample size and bars indicate standard error.

VH34(95)]. Linkage disequilibrium was clearly not complete, however, and other combinations of alleles were also observed.

Due to the degree of over-dispersion in the FEC data, GLMs were constructed assuming a negative binomial error structure (Wilson, Grenfell \& Shaw, 1996; Wilson \& Grenfell, 1997). Year, weight, and 
Table 7. Generalized linear models of over-winter survival in Soay sheep lambs (A) and yearlings (B)

(Models were fitted assuming a binomial error structure. The change in total deviance explained is equal to the amount of deviance explained by that term when fitted last, divided by the sum of the explained deviances of all terms when fitted last, expressed as a percentage of the total deviance explained by the full model. Coefficients for significant terms and their standard errors were estimated from 2500 bootstrap replications of the model. $P$ values indicate the level of statistical significance estimated asymptotically by deletion testing.)

\begin{tabular}{|c|c|c|c|c|}
\hline Term & D.F. & $\begin{array}{l}\text { Deviance } \\
\text { explained }(\%)\end{array}$ & Coefficient (s.E.) & $P$ \\
\hline \multicolumn{5}{|c|}{ A Lambs (age 4 months): $N=630$, total deviance $=871 \cdot 3$, residual deviance $=693.8$} \\
\hline Year & 11 & $17 \cdot 7$ & & $<0 \cdot 0001$ \\
\hline Weight & 1 & $1 \cdot 4$ & $+0 \cdot 124(0 \cdot 039)$ & $0 \cdot 001$ \\
\hline Twin & 2 & $1 \cdot 2$ & $\begin{array}{r}\text { Twin: }-0.294(0.123) \\
\text { Singleton: }+0.259(0.112)\end{array}$ & $0 \cdot 009$ \\
\hline \multicolumn{5}{|c|}{ Rejected terms } \\
\hline Sex & 1 & & & $0 \cdot 051$ \\
\hline BL4 & 2 & & & $0 \cdot 58$ \\
\hline VH34 & 3 & & & $0 \cdot 60$ \\
\hline $\mathrm{o}(\mathrm{IFN})-\gamma$ & 1 & & & $0 \cdot 87$ \\
\hline \multicolumn{5}{|c|}{ B Yearlings (age 16 months): $N=226$, total deviance $=233 \cdot 7$, residual deviance $=174 \cdot 8$} \\
\hline Year & 9 & $12 \cdot 2$ & & $<0.0001$ \\
\hline Weight & 1 & $7 \cdot 8$ & $+0.297(0.069)$ & $<0.0001$ \\
\hline Sex & 1 & $5 \cdot 1$ & Male: $-0.823(0 \cdot 222)$ & $<0 \cdot 0001$ \\
\hline \multicolumn{5}{|c|}{ Rejected terms } \\
\hline BL4 & 2 & & & $0 \cdot 47$ \\
\hline VH34 & 3 & & & $0 \cdot 68$ \\
\hline$o(\operatorname{IFN})-\gamma$ & 1 & & & $0 \cdot 64$ \\
\hline
\end{tabular}

sex were the most important sources of variation in FEC at 4 and 16 months of age (Table 5). At both ages, the 126 allele at the $\mathrm{o}(\mathrm{IFN})-\gamma$ locus was significantly associated with reduced FEC. This effect is illustrated in Fig. 3 and is more strongly evident in yearlings. In lambs, 126/126 homozygotes have on average $9.4 \%$ lower FEC than 130/130 homozygotes; in yearlings the difference is $31.2 \%$ (Fig. 3). Alleles at the 2 flanking loci did not show significant association with FEC at either age (Table $5)$. The maternal o(IFN)- $\gamma$ genotype did not explain significant variation in FEC at either age when fitted in either reduced model containing the offspring genetic term (4 months: $N=620, P=0.63$; 16 months: $N=214, P=0 \cdot 14)$.

IgA titre was modelled assuming a normal error structure following logarithmic transformation. At 4 months of age IgA varied between years and was positively related to age in days since birth (Table 6A). Twins also had significantly higher IgA titre than singletons at 4 months. At 4 months of age, IgA titre was significantly associated with alleles at $o(\mathrm{IFN})-\gamma$, with the 126 allele in positive association with IgA titre (Fig. 4). At 16 months of age only year explained significant variation in IgA (Table 6B); however, there was a trend for $\operatorname{IgA}$ to increase with the number of 126 alleles at o(IFN)- $\gamma$ (Fig. 4). The maternal o(IFN) $-\gamma$ genotype did not explain significant variation in IgA measured in lambs when fitted either as a main effect $(N=304, P=0.93)$ or as an interaction with lamb age $(P=0 \cdot 73)$.
Over-winter survival was modelled assuming a binomial error structure. Mean over-winter survival averaged over all cohorts was $58.9 \%$ for the first winter and $81.4 \%$ for the second. Variation in survival was affected by year and weight over both intervals (Table 7). First winter survival was reduced in twins, and females were more likely to survive their second winter. Survival was clearly not associated with alleles at any of the three loci considered ( $P>0.5$ for each locus).

\section{DISCUSSION}

FEC was significantly associated with alleles at the $o($ IFN $)-\gamma$ microsatellite locus, and not with alleles at flanking markers, suggesting there to be a QTL associated with reduced FEC segregating near the (IFN)- $\gamma$ gene in Soay sheep. This result independently verifies the Crawford \& McEwen's (1998) findings in an unmanaged, naturally-parasitized population. Furthermore, our results indicate that the $o(\mathrm{IFN})-\gamma_{126}$ allele associated with reduced FEC is also significantly associated with increased titre of Teladorsagia-specific IgA in lambs independent of the maternal genotype, and suggest an association at 16 months. Clearly, more IgA data need to be collected in order to resolve the association in older sheep further as the sample taken at 16 months of age was small $(N=101$ individuals typed at all 3 loci) and probably lacked the statistical power to detect an association with IgA if one existed. However, it is 
also possible that resistance to gastrointestinal parasites is mediated by other mechanisms in older sheep (Stear, Strain \& Bishop, 1999b).

The results from sheep aged 4 months merit speculation that there may be a direct link between interferon gamma expression, IgA production and resistance to nematode infection in young sheep. When FEC data were analysed in a GLM including both IgA and o(IFN)- $\gamma_{126}$ alleles, IgA titre explained significant variation $(P<0 \cdot 0001$, accounting for $3.1 \%$ of the total variance) when fitted before o(IFN)- $\gamma_{126}$, which became non-significant $(P=$ $0 \cdot 077)$. This indicates that the effects of o(IFN)- $\gamma$ and IgA on FEC were not independent, and suggests that the (IFN)- $\gamma$ effect on FEC may be mediated by IgA. Stear and coworkers (Stear, Strain \& Bishop, $1999 a, b)$ have found that genetic variation in egg output in lambs subjected to natural $T$. circumcincta infection is caused by variation in worm length, which is controlled by the strength and molecular specificity of the local IgA response against 4th-stage larvae.

Experimental evidence from other mammalian systems illustrates the key role played by (IFN) $-\gamma$ in regulating the antibody response including $\mathrm{IgA}$. In rat and mouse models, the $\mathrm{Th}_{2}$ cell subset is primarily responsible for orchestrating antibody responses to helminth infection, and the activity of this subset, which is down-regulated by the production of interferon gamma, dramatically increases during the response to infection in resistant lines (Else \& Finkelman, 1998; Ishikawa et al. 1998; Stewart et al. 1999). However, susceptible strains of mice that fail to expel worms following deliberate infection have a $\mathrm{Th}_{1}$ dominant subset as evidenced by a cytokine expression profile dominated by (IFN)- $\gamma$ (Else et al. 1994). In vivo depletion of (IFN) $-\gamma$ in the genetically susceptible lines then led to the expulsion of worms (Else et al. 1994).

We were surprised to find there to be no association between the putative resistance allele $o(\operatorname{IFN})-\gamma_{126}$ and over-winter survival probability in either age class. Our data set was of sufficient size to detect such an effect $(N=630$ and 226) with reasonable power, and in the past we have found that genetic factors associated with resistance were also associated with increased survival using similar methods (Coltman et al. 1999 b; Gulland et al. 1993; Paterson et al. 1998). We can speculate on 2 possible explanations for this result. First, the (IFN)- $\gamma$ QTL may affect worm fecundity without appreciably influencing the cost of the parasites to host survival. While Stear and coworkers (Stear et al. 1995, 1996, $1997,1999 b$ ) have shown that in domestic lambs genetic variation for $\mathrm{FEC}$ is manifest as reduced adult female worm length, from our data it is not possible to determine whether the (IFN)- $\gamma$ QTL confers reduced total parasite burden or cost. Nonetheless, if the QTL were associated with a reduction in egg output, this is a still very desirable trait from the epidemiological perspective as egg output is the primary determinant of larval abundance in the pasture.

Alternately, the QTL may provide a survival advantage with respect to resistance to parasitic nematodes, yet also incur costs in other ways such as increased susceptibility to intracellular pathogens. For example, if the resistance QTL resulted from suppressed (IFN)- $\gamma$ expression and enhanced $\mathrm{Th}_{2}$ response, the same individual would be at greater risk from infection by bacteria, fungi and viruses due to suppression of the $\mathrm{Th}_{1}$ pathway, and could experience type 1-like hypersensitivity (Pritchard, Hewitt \& Moqbel, 1997). In this case, if the fitness advantage of an enhanced $\mathrm{Th}_{2}$ response with respect to resistance to nematode was balanced by the cost of increased susceptibility to microbial infection, then the polymorphism could be maintained in the population by balancing selection or antagonistic pleiotropy.

While it is tempting to speculate that a functional polymorphism at the (IFN)- $\gamma$ gene leading to differential expression or sensitivity may be the source of the QTL effect, we have no direct evidence to support this idea from this study. Future research aimed at determining whether the marker allele is associated with immunological parameters, such cytokine production in vivo (Finkelman \& Morris, 1999), is warranted. It is also possible that the effect may be caused by another as yet uncharacterized gene in the vicinity of (IFN)- $\gamma$. Finally, a frequent criticism of association studies such as this one is that associations between marker alleles and traits can arise due to population structure or admixture. For example, if family groups or clusters of related individuals with different frequencies of marker alleles tended to graze pastures differing in the abundance of infective larvae, then an association between marker alleles and parasitism could arise without any immunogenetic basis. In this circumstance we would expect associations to arise with the flanking marker loci equally frequently, or perhaps more frequently due to their greater polymorphism. This was not the case in this study for FEC, as only $o($ IFN $)-\gamma$ showed significant associations. However, the transmission disequilibrium (TD) test for quantitative traits offers a more powerful statistical procedure that is resistant to confounding due to population structure (Allison, 1997; Rabinowitz, 1997). TD tests require full pedigree knowledge and the knowledge of the parental marker genotypes, however. We are currently expanding our o(IFN)- $\gamma$ typing efforts to include both parents where known, as we have knowledge of many paternal links in the population through molecular paternity inference (Pemberton et al. 1999).

The findings of this study independently verify Crawford \& McEwen's (1998) discovery of a QTL 
conferring resistance to gastrointestinal nematodes located near the (IFN)- $\gamma$ gene in domestic sheep. Given the long separation time between the primitive Soay and the breeds in which the QTL was originally detected (Romney and Merino), it is likely to be widely spread among domestic sheep. While it is possible that the QTL is caused by a genetic polymorphism resulting in differential expression of (IFN)- $\gamma$ and subsequent modulation of the $\mathrm{Th}_{1} / \mathrm{Th}_{2}$ response, more data are needed to ascertain the immunological basis of resistance associated with this polymorphism.

We thank Alan Crawford for sharing his QTL findings with us, and for encouraging the investigation of the interferon gamma gene in our study system. We thank the National Trust for Scotland and Scottish Natural Heritage for permission to work on St Kilda, and the Royal Artillery Range (Hebrides), the Royal Corps of Transport, DERA and SERCo for logistical assistance. We thank Steve Albon, Tim Clutton-Brock, Mick Crawley and Bryan Grenfell and the numerous staff and volunteers who have helped in the data collection on St Kilda. Frances Gulland initiated parasite monitoring in the population. Justine Boles performed the IgA assays. An anonymous reviewer provided valuable comments on an earlier draft of this manuscript. This research was funded by the Wellcome Trust, the Natural Environment Research Council and the Biotechnology and Biological Sciences Research Council.

\section{REFERENCES}

ALlison, D. B. (1997). Transmission-disequilibrium tests for quantitative traits. American Fournal of Human Genetics 60, 676-690.

BANCROFT, D. R., PEMBERTON, J. M. \& KING, P. (1995). Extensive protein and microsatellite variability in an isolated, cyclic ungulate population. Heredity 74, 326-336.

BEH, K. J. \& MADdox, J. F. (1996). Prospects for development of genetic markers for resistance to gastrointestinal parasite infection in sheep. International Fournal for Parasitology 26, 879-897.

BISHOP, s. C., BAIRDEN, K., McKellar, Q. A., PARK, M. \& STEAR, M. J. (1996). Genetic parameters for faecal egg count following mixed, natural, predominantly Ostertagia circumcincta infection and relationships with live weight in young lambs. Animal Science 63, 423-428.

Clutton-Brock, T. H., PRICE, O. F., Albon, S. D. \& JEwell, P. (1991). Persistent instability and population regulation in Soay sheep. Fournal of Animal Ecology 54, 831-846.

Clutton-Brock, T. H., PRICE, O. F., Albon, S. D. \& JEWELL, P. (1992). Early development and population fluctuations in Soay sheep. Fournal of Animal Ecology 61, 381-396.

COLTMAN, D. W., BANCROFT, D. R., ROBERTSON, A., SMITH, J. A., Clutton-Brock, T. H. \& Pemberton, J. M. $(1999 a)$. Male reproductive success in a promiscuous mammal: behavioural estimates compared with genetic paternity. Molecular Ecology 8, 1199-1209.
COLTMAN, D. W., Pilkington, J. G., SMith, J. A. \& Pemberton, J. M. (1999 b). Parasite-mediated selection against inbred Soay sheep in a free-living, island population. Evolution 53, 1259-1267.

CRAWFORD, A. M. \& MCEWEN, J. C. (1998). Identification of Animals Resistant to Nematode Parasite Infection. New Zealand Provisional Patent 330201. New Zealand.

CRAWFord, A. M., PHUA, S. H., McEWAN, J. C., DODDS, K. G., Wright, C. C., MORRIS, C. A., BISSET, S. A. \& GREEN, R. S. (1997). Finding disease resistance QTL in sheep. Animal Biotechnology 8, 13-22.

CRAWLEY, M. J. (1993). GLIM for Ecologists. Blackwell Scientific Publications, Oxford.

DE Gortari, M. J., Freking, B. A., Cuthbertson, R. P., KAPPES, S. M., KEELE, J. W., STONE, R. T., LEYMASTER, K. A., DODDS, K. G., CRAWFORD, A. M. \& BEATtie, C. W. (1998). A second-generation linkage map of the sheep genome. Mammalian Genome 9, 204-209.

ELSE, K. J. \& FINKELMAN, F. D. (1998). Intestinal nematode parasites, cytokines and effector mechanisms. International Fournal for Parasitology 28, 1145-1158.

ELSE, K. J., FINKELMAN, F. D., MALISZEWSKi, C. R. \& GRENCIS, R. K. (1994). Cytokine-mediated regulation of chronic intestinal helminth infection. Fournal of Experimental Medicine 179, 347-351.

FINKELMAN, F. D. \& MORRIS, s. C. (1999). Development of an assay to measure in vivo cytokine production in the mouse. International Immunology 11, 1811-1818.

GOLDAMMER, T., BRUNNER, R. M., SCHMIDT, P. \& SCHWERIN, M. (1996). Mapping of the interferon gamma gene (IFNG) to chromomes 3 in sheep and 5 in goat by FISH. Mammalian Genome 7, 470-471.

GRENCIS, R. K. (1997). Th2-mediated host protective immunity to intestinal nematode infections. Philosophical Transactions of the Royal Society, Series B-Biological Sciences 352, 1377-1384.

GRENFEll, B. T., PRICE, O. F., ALBON, S. D. \& CLUTTONBROCK, T. H. (1992). Overcompensation and population cycle in an ungulate. Nature, London 355, 823-826.

GRENFELL, B. T., WILSON, K., FINKENSTADT, B. F., COUlson, T. N., Murray, S., Albon, S. D., PEMBERTON, J. M., ClutTon-Brock, T. H. \& CRAWLEY, M. J. (1998).

Noise and determinism in synchronized sheep dynamics. Nature, London 394, 674-677.

GULLAND, F. M. D. (1992). The role of nematode parasites in Soay sheep (Ovis aries L.) mortality during a population crash. Parasitology 105, 493-503.

GUlland, F. M. D., Albon, S. D., PEMBERTon, J. M., MOORCROFT, P. R. \& CLUTtON-Brock, T. H. (1993). Parasite-associated polymorphism in a cyclic ungulate population. Proceedings of the Royal Society, B 254, 7-13.

GULland, F. M. D. \& FOX, M. (1992). Epidemiology of nematode infections of Soay sheep (Ovis aries L.) on St Kilda. Parasitology 105, 481-492.

illius, A. W., Albon, S. D., PEMBERTON, J. M., GORDON, I. J. \& Cluttonbrock, T. H. (1995). Selection for foraging efficiency during a population crash in Soay sheep. Fournal of Animal Ecology 64, 481-492.

ISHIKAWA, N., GOYAL, P. K., MAHIDA, Y. R., LI, K. F. \& WAKELIN, D. (1998). Early cytokine responses during intestinal parasitic infections. Immunology 93, 257-263. 
MINISTRY OF AGRICULTURE, FISHERIES AND FOOD (1971). Manual of Veterinary Parasitological Laboratory Techniques. HMSO, London.

PAterson, s., Wilson, K. \& PEMberton, J. M. (1998).

Major histocompatibility complex variation associated with juvenile survival and parasite resistance in a large unmanaged ungulate population (Ovis aries L.).

Proceedings of the National Academy of Sciences, USA 95, 3714-3719.

Pemberton, J. M., Coltman, D. W., SMith, J. A. \& Pilkington, J. G. (1999). Molecular analysis of a promiscuous, fluctuating mating system. Biological Fournal of the Linnean Society 68, 289-301.

PIERSON, C. A., HANRAHAN, V., EDE, A. J. \& CRAWFORD, A. M. (1993). Ovine microsatellites at the OarVH34, OarVH41, OarVH58, OarVH61 and OarVH72 loci. Animal Genetics 24, 224.

PRICHARD, R. (1994). Anthelmintic resistance.

Veterinary Parasitology 54, 259-268.

PRITCHARD, D. I., HEWITT, C. \& MOQBEL, R. (1997).

Relationship between immunological responsiveness controlled by T-helper 2 lymphocytes and infections with parasitic helminths. Parasitology 115, S33-S44.

RABINOWITZ, D. (1997). A transmission disequilibrium test for quantitative trait loci. Human Heredity 47, 342-350.

RAYMOND, M. \& ROUSSET, F. (1995). Genepop (Version1.2)-Population-genetics software for exact tests and ecumenicism. Fournal of Heredity 86, 248-249.

READ, A. F., ALbON, S. D., ANTONOVICs, J., APANiUS, V., DWYER, G., HOLT, R. D., JUDSON, O., LIVELY, C. M., MARTIN-LOF, A., MCLEAN, A. R., METZ, J. A. J., SCHMIDHeMPel, P., THRAll, P. H., Via, S. \& Wilson, K. (1995). Group report: genetics and evolution of infectious diseases in natural populations. In Ecology of Infectious Diseases in Natural Populations (ed. Grenfell, B. T. \& Dobson, A. P.), pp. 450-477. Cambridge University Press, Cambridge.

RICE, W. R. (1989). Analyzing tables of statistical tests. Evolution 43, 223-225.

Roos, M. H. (1997). The role of drugs in the control of parasitic nematode infections: must we do without? Parasitology 114, S137-S144.

SChmidt, P., LUDT, C., KUhn, c. \& Buitkamp, J. (1996). A diallelic tetranucleotide repeat, $(\mathrm{GT}(3))(5$ or 6$)$, within intron 1 of the ovine interferon-gamma gene. Animal Genetics 27, 437-438.

SCHWAiger, F. W., GOSTOMSKi, D., STEAR, M. J., DUNCAN, J. L., McKellar, Q. A., Epplen, J. T. \& Buitkamp, J. (1995). An ovine major histocompatibility complex Drb1 allele is associated with low fecal egg counts following natural, predominantly Ostertagia circumcincta infection. International Fournal for Parasitology 25, 815-822.

SINSKi, E., BAIRDEN, K., DUNCAN, J. L., EISLER, M. C., holmes, P. H., McKellar, Q. A., MURRAy, M. \& STEAR, M. J. (1995). Local and plasma antibody responses to the parasitic larval stages of the abomasal nematode
Ostertagia circumcincta. Veterinary Parasitology 59, 107-118.

SMith, J. A., WILSON, K., PILKington, J. G. \& PEMBERTON, J. M. (1999). Heritable variation in resistance to gastro-intestinal nematodes in an unmanaged mammal population. Proceedings of the Royal Society, B 266, 1283-1290.

SMith, T. P. L., LOPEZ-CORRAle, N., GRosz, M. D., Beattie, C. W. \& KAPPE, S. M. (1997). Anchoring of bovine chromosomes 4, 6, 7, 10, and 14 linkage group telomeric ends via FISH analysis of lambda clones. Mammalian Genome 8, 333-336.

Stear, M. J., Bairden, K., DUNCAN, J. L., holmes, P. H., MCKELLAR, Q. A., PARK, M., STRAIN, S., MURRAY, M., BISHOP, s. C. \& GETTINBY, G. (1997). How hosts control worms. Nature, London 389, 27.

STEAR, M. J., BISHOP, S. C., DOLIGALSKA, M., DUNCAN, J. L., HOLMES, P. H., IRVINE, J., MCCRIRIE, L., MCKEllaR, Q. A., SINSKi, E. \& MURRAY, M. (1995). Regulation of egg production, worm burden, worm length and worm fecundity by host responses in sheep infected with Ostertagia circumcincta. Parasite Immunology 17, 643-652.

STEAR, M. J., PARK, M. \& BISHOP, S. C. (1996). The key components of resistance to Ostertagia circumcincta in lambs. Parasitology Today 12, 438-441.

STEAR, M. J., STRAin, S. \& BISHOP, S. C. $(1999 a)$. How lambs control infection with Ostertagia circumcincta. Veterinary Immunology and Immunopathology 72, 213-218.

STEAR, M. J., STRAIN, S. \& BISHOP, s. C. (1999b). Mechanisms underlying resistance to nematode infection. International Fournal for Parasitology 29, 51-56.

STEVENSON, I. R. \& BANCROFT, D. R. (1995). Fluctuating trade-offs favour precocial maturity in male Soay sheep. Proceedings of the Royal Society, B 262, $267-275$

STEWART, G. L., NA, H., SMART, L. \& SEElig, L. L. (1999). The temporal relationship among anti-parasite immune elements expressed during the early phase of infection of the rat with Trichinella spiralis. Parasitology Research 85, 672-677.

Wakelin, D. (1996). Immunity to Parasites: How Parasitic Infections are Controlled. Cambridge University Press, Cambridge.

WEIR, B. s. (1979). Inferences about linkage disequilibrium. Biometrics 35, 235-254.

WILSON, K. \& GRENFELL, B. T. (1997). Generalized linear modelling for parasitologists. Parasitology Today 13, 33-38.

WILSON, K., GRENFELL, B. T. \& SHAW, D. J. (1996). Analysis of aggregated parasite distributions: A comparison of methods. Functional Ecology 10, 592-601.

WOOlaston, R. R. \& BAKER, R. L. (1996). Prospects of breeding small ruminants for resistance to internal parasites. International Fournal for Parasitology 26, 845-855. 